\title{
Copturus eximius.
}

C. ovatus, ater, prothorace supra (medio excepto) elytrisque plaga magna tripartita coccineis ; femoribus infra bidentatis, posticis valde elongatis. Long. 3 lin.

\section{Hab. Columbia.}

Ovate, jet-black, with bright scarlet patches on the prothorax and elytra; rostrum elongate, slender, broader towards the tip, glossy brown; antennæ fulvous, scape short, funicle long, the second joint twice as long as the first; prothorax transverse, rounded at the base, a black spot in the middle, and the sides black, the rest covered with scarlet scales; scutellum black; elytra rather shorter, broadly rounded at the apex, punctate-striate, a broad scarlet band rather behind the middle and continued anteriorly along the suture to the base; sides of the sterna, second and third abdominal segments closely covered with yellow scales; femora slender, sinuate beneath, and in the sinus two teeth, the proximal by far the largest; posterior femora very long, their tibiæ at the apex, and tarsi, except the last joint, ochraceous, claws fulvous; pectoral canal extending to the intermediate coxæ.

This beautiful species is remarkable for its long posterior femora, which extend for more than half their length beyond the elytra. The pectoral canal extends to the anterior border of the metasternum.

\section{MISCELLANEOUS.}

On the Origin and Development of the Ovum in Encope before Fecundation. By М. С. МеRejкowsky.

THe ovaries of the Medusa, arranged in the interior of the bell, have the appearance of four little sacs, produced by an evagination of the gastrovascular cavity. In the walls of the ovaries, from without inwards, we find a layer of ectodermic cells, the limits of which are not well defined, and the entoderm composed of several layers of better-defined cells. The innermost layer of the entoderm, that which covers the inner surface of the ovary, is composed of the same cells (furnished with a vibratile cilium) as the entoderm of the radial canals.

Towards the base of the ovary, where it becomes confounded with the lower surface of the bell, the entodermic layer is as yet only formed of a single stratum, as in the radial canal; but in proportion as we advance towards the interior of the ovary, we see the entodermic cells divide in a direction perpendicular to their length, and thus form two superposed layers of entoderm; the 
division of the cells continuing in all directions, we thus find the entoderm grow thicker and thicker.

Between these two lamellæ of entoderm and ectoderm forming the ovary, there is a third, more delicate lamella destitute of structure; this is the intermediate lamella, which separates them in a very marked manner, and assists to define with certainty which layer produces the ova of the Encope; these ova always occurring beneath the intermediate lamella, and being thus separated by that lamella from the ectoderm, can only be developed from the entoderm. But another reason leads us to accept the entodermic origin of the ova of the Encope, if we observe directly all the graduated transitions between the ordinary entodermic cells and the young ova. The changes in an entodermic cell destined to be developed into an ovum, which I must now notice, consist in the increase of the volume of this cell and the transformation of the nucleus into a germinal spot.

In the entodermic cells lining the radial canals, the protoplasm is perfectly transparent and destitute of granules; the nucleus appears in the form of a clear round spot, containing at the centre a round nucleolus of greater density. Subsequently we observe that the cells, as well as their nuclei and nucleoli, increase in size, and the protoplasm becomes more and more granular. The nucleolus, which is at first simple and furnished with a small vacuole, begins to divide. As I have described in the case of a Medusa of the White Sea *, at the commencement of the division the nucleolus elongates, becomes constricted in the middle, makes a bend which gives it the form of a horse-shoe, and finally divides into two parts, each of which possesses a central vacuole; then each half divides again (simultareously or not) into two parts, but in a direction perpendicular to the first (as in the segmentation of the ovum), and so on.

Although these phenomena are constant and normal in the Medusæ of the White Sea, I have only observed them exceptionally in the Medusæ of the Gulf of Naples. Usually in the latter the division of the nucleus takes place in a perfectly different manner, which has not yet been described. When, after it has become elongated, the nucleolus presents a median constriction, it does not divide into two parts, but simply becomes elongated in the form of a band twisted upon itself; constrictions then forming at various parts of it, the nucleolus, from being originally round, becomes a long moniliform ribbon rolled up in several turns. Each division of the chaplet is fusiform and round; it regularly contains in the middle a very small vacuole, and is united to the neighbouring divisions by a thin and sometimes rather long articulation. Sometimes this long sinuous band, which reminds us of the nucleus of certain Infusoria (Stentor, Spirostomum), splits into two bands. Finally the grains or articulations of the chaplet separate, and,

* "Studies on Hydroida," Ann. \& Mag. Nat. Hist. ser. 5, vol. i. p. 254, pl. xiii. figs. 9-14 (1878). 
instead of a nucleolus, there is formed at the centre of the nucleus a whole group of several dozens of small round balls, which collect into a sphere placed at some distance from the walls of the nucleus. Afterwards these balls continue to divide for some time, thus becoming more and more minute at the same time that their number reaches several hundred. During all the time that these phenomena are being produced the ovum enlarges and attains its definitive diameter, which is nearly twenty times that of the entodermic cells which gave origin to the ovum.

The definitive aspect of the perfectly mature ovum before fecundation is that of a sphere of granular protoplasm with a central and perfectly uniform nucleus, showing not the smallest trace of any nucleolus whatever. The hundreds of granules into which the nucleolus has been divided have become dissolved in the protoplasm of the nucleus. cells.

Summary.-1. The ova of Encope are developed from entodermic

2. The nucleolus acquires the form of a chaplet twisted upon itself; the grains of the chaplet become isolated and continue to divide.

3. The mature ovum before fecundation has no longer the least trace of a nucleolus in its nucleus, which is entirely homogeneous. -Comptes Rendus, April 26, 1880, p. 1012.

\section{Observations on the Megapodes. By M. E. Oustalet.}

A commission given to me by the École des Hautes Études having enabled me to visit the great museums of England and Holland, I have been able to complete the investigations that I hud undertaken upon the Gallinaceous birds of the family Megapodiidæ, and I have ascertained that the number of species admitted by modern ornithologists is too large, and may be reduced to about twenty-five.

By a comparative study of skeletons of Talegallas, Maléos (Megacephalon), Megapodes, Guans (Penelope), and Guinea-fowl, I have also ascertained that the creation of a separate group, proposed by Prof. Huxley*, that of the Peristeropodes, including the two families Cracidæ and Megapodiidæ, was fully justified; but that the Pintados present certain analogies of structure with these birds which that learned zoologist has not, perhaps, sufficiently brought out.

On dissecting a Talegalla I met with certain arrangements indicated by Dr. Garrod in the Maléo; but, on the other hand, I remarked that other peculiarities in the mode of insertion of the muscles of the wing and leg were not of so much zoological importance as that anatomist thought it right to ascribe to them.

Again, on examining a collection recently sent by M. Bruijn I found that Talegallus jobiensis also occurs on the continent of New Guinea, and that $T$. pyrrhopygius, when adult, possesses a wattle on the front of the neck, and that it always has the nostrils rounded

* "On the Alectoromorphæ," in Proc. Zool. Soc. 1868. 


\section{$2 \mathrm{BHL}$ Biodiversity Heritage Library}

Merejkowsky, M C. 1880. "On the origin and development of the ovum in Encope before fecundation." The Annals and magazine of natural history; zoology, botany, and geology 5, 498-500.

https://doi.org/10.1080/00222938009459450.

View This Item Online: $\underline{\text { https://www.biodiversitylibrary.org/item/55148 }}$

DOI: https://doi.org/10.1080/00222938009459450

Permalink: https://www.biodiversitylibrary.org/partpdf/57103

\section{Holding Institution}

Smithsonian Libraries

\section{Sponsored by}

Smithsonian

\section{Copyright \& Reuse}

Copyright Status: Public domain. The BHL considers that this work is no longer under copyright protection.

This document was created from content at the Biodiversity Heritage Library, the world's largest open access digital library for biodiversity literature and archives. Visit BHL at https://www.biodiversitylibrary.org. 